\title{
Evaluation of Anti-Anxiety Effect of Brassica oleracea L. Extracts in Experimental Animals
}

\author{
Divneet Kaur ${ }^{1}$, Richa Shri², Anjoo Kamboj ${ }^{3}$
}

\section{Divneet Kaur, ${ }^{1}$ Richa Shri, ${ }^{2}$ Anjoo Kamboj. ${ }^{3}$}

\section{II.K.Gujral Punjab Technical University, Jalandhar, INDIA. \\ ${ }^{2}$ Department of Pharmaceutical Sciences and Drug Research, Patiala, INDIA. \\ ${ }^{3}$ Chandigarh College of Pharmacy, Landran, Mohali, Punjab, INDIA. \\ Correspondence}

Anjoo kamboj, Chandigarh College of Pharmacy, Landran, Mohali, Punjab. INDIA.

\section{Tel.: 9781925296}

E-mail: anjookamboj@gmail.com

\section{History}

- Submission Date: 06-04-2017;

- Review completed: 08-06-2017;

- Accepted Date: 09-06-2017

\section{DOI : 10.5530/pj.2017.5.101}

Article Available online

http://www.phcogj.com/v9/i5

\section{Copyright}

(C) 2017 Phcog.Net. This is an openaccess article distributed under the terms of the Creative Commons Attribution 4.0 International license.

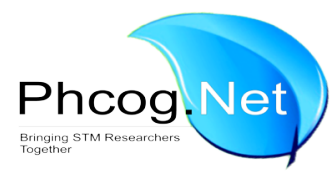

\begin{abstract}
Introduction: Oxidative stress in the brain causes nervous system impairment. Hence the use of antioxidants could be an effective approach to prevent disorders such as anxiety. Plants containing phenolic constituents are reported to be potent antioxidants. Brassica oleracea L. commonly known as broccoli, is rich in phenolics mainly flavonoids and possesses excellent antioxidant property, however its anxiolytic potential has not been investigated. Thus in the present study antianxiety activity of extracts of broccoli was evaluated in experimental animals. Materials and Methods: Various pharmacognostic parameters of the plant material were studied following standard procedures. Groups of six mice each were taken as different treatment groups. Control group received vehicle (1\% Carboxy Methyl Cellulose), positive control received Diazepam $(2 \mathrm{mg} / \mathrm{kg})$ as standard drug while test groups received petroleum ether and hydroalcoholic extracts $(50,100$ and $200 \mathrm{mg} / \mathrm{kg}$ body weight, p.o.). The effects were evaluated on Elevated Plus Maze (EPM), hole board and mirror chamber tests. Statistical analysis was performed using ANOVA, followed by Turkey's post-hoc test. Results: Hydroalcoholic extract shows dose dependent increase in the average time spent and frequency of entries in the open arms of the EPM; decreased latency, increased time spent and frequency of entries in the mirror chamber; increased number of head dips in hole board test as compared to control was observed. These effects were comparable to the effect produced by diazepam. Phytochemical screening of the bioactive extract revealed the presence of alkaloids, phenols, flavonoids and tannins. Conclusion: From our study, it can be concluded that hydroalcoholic extract of Brassica oleracea at the dose of $200 \mathrm{mg} / \mathrm{kg}$ possesses marked anxiolytic activity.

Key words: Antianxiety, Brassica oleracea, Elevated Plus Maze, Hole Board, Mirror Chamber Test.
\end{abstract}

\section{INTRODUCTION}

Anxiety is an adaptive emotion that permits physiological and behavioural changes, to appropriately react to a stressful situation to resolve it by fighting or escaping. Anxiety disorder is defined as a feeling of apprehension, uncertainty or tension stemming from the anticipation of imagined or unreal threat. ${ }^{1}$ Anxiety affects one-eighth of the population worldwide and has debilitating effects on the quality of life of many people. $^{2}$

Anxiety disorders can be identified by early diagnosis and effective treatment includes psychotherapy and use of drugs like benzodiazepines. ${ }^{3-4}$ Conventional drug therapy have a narrow margin of safety between the anxiolytic effect and unwanted side effects, thus prompting researchers to evaluate new compounds specially plant based drugs having less undesirable effects. ${ }^{5}$

Oxidative stress in the brain causes nervous system impairment. Oxidative stress has also been implicated in depression and anxiety disorders. ${ }^{6}$ Studies have revealed that antioxidants have a key role as an adju- vant therapy in patients with generalized anxiety disorder and depression. ${ }^{7}$ Flavonoids are reported to be potent antioxidants. ${ }^{8-10}$ Many plants containing flavonoids are reported to possess anxiolytic potential. ${ }^{11-12}$ Some of the plants containing flavonoids demonstrating antianxiety activity are Abies pindrow, ${ }^{13}$ Calotropis gigantean, ${ }^{14}$ Matricaria recutita, ${ }^{15}$ Gelsemium sempervirens, ${ }^{16}$ Medicago sativa, ${ }^{17}$ Passiflora coerulea, ${ }^{18}$ Passiflora incarnate, ${ }^{19}$ Tilia Americana, ${ }^{20}$ Turnera aphrodisiaca. ${ }^{21-22}$ Flavonoids which possess anxiolytic effects include apigenin, ${ }^{23}$ chrysin, kaempferol, ${ }^{24}$ quercetin. ${ }^{25}$

In the present study Brassica oleracea L., also known as broccoli, which belongs to family Brassicaceae has been evaluated for its anxiolytic potential. Broccoli is an edible green plant in the cabbage family whose large flower head is eaten as a vegetable. Like other species of the Brassica family, broccoli is a rich source of health promoting phytochemicals. ${ }^{26,27}$ It is rich in phenolic compounds, particularly flavonoids. It also contains ascorbic acid, vitamins $\mathrm{C}$ and 
E, amino acid, the flavonols quercetin and kaempferol, the carotenoids b-carotene, lutein, and the glucosinolates. ${ }^{28}$ This is reported to have anti-oxidant, anti-microbial, gastroprotective, anti-cancer, anti-diabetic, cardioprotective and hepatoprotective effects. ${ }^{29-35}$

Broccoli (Brassica oleracea) contains phenolic compounds and has marked antioxidant activity has been selected and evaluated for its anxiolytic potential. This plant has never been evaluated for their antianxiety potential, therefore it was investigated for its anxiolytic potential. So the aim of the present investigation was to study pharmacognostic parameters and to evaluate the antianxiety activity of petroleum ether and hydroalcoholic extract of Brassica oleracea using Elevated Plus Maze (EPM), hole board and mirror chamber tests of anxiety.

\section{MATERIALS AND METHODS}

\section{Collection and authentication of plant material}

Flower heads of Brassica oleracea were procured from Punjab Agricultural University, Ludhiana, India in the month of January 2015. Identity of the plant was confirmed by Head, Raw Materials, Herbarium \& Museum at National Institute of Science Communication and Information Resources (NISCAIR), New Delhi, India, vide letter number/ NISCAIR/ RHMD/Consult/2014/2577-156 dated 13.02.2015

\section{Drugs and chemicals}

Diazepam was obtained from GlaxoSmithKline and petroleum ether, methanol (LR grade) were procured from S.D. Fine-Chem Ltd, Mumbai.

\section{Physicochemical evaluation}

The determination of physicochemical parameter is important in determination of adulterants and improper handling of drugs. Various physicochemical parameters were studied following standard procedures. ${ }^{36}$ All parameters such as moisture content (LOD method), ash values, extractive values were determined in triplicate.

\section{Preparation of extract}

The plant was dried in shade and powdered. Powdered drug (750 g) was subjected to successive exhaustive extraction with petroleum ether and methanol:water (70:30) in the Soxhlet apparatus. Petroleum ether (PE) and hydroalcoholic (HA) extracts were dried using rotary evaporator and yield calculated on dry weight basis. Dried extracts were preserved in vacuum desiccator. These solvents selected for extraction were selected broadly to get a non polar and a polar extract.

\section{Phytochemical screening}

A phytochemical examination was carried out for both the extracts as per standard methods. ${ }^{37}$

\section{Animals}

Swiss albino mice (weighing 15-30g) were taken from Chandigarh College of Pharmacy, Landran (Regd. No. 1201/a/08/CPCSEA) and kept in polypropylene cages of 5 mice at $22 \pm 1^{\circ} \mathrm{C}$ on a 12 -h light/dark cycle. Water and food were available ad libitum. Groups of six mice were randomly assigned to different treatment groups. Control group received vehicle, one group was given standard drug Diazepam ( $2 \mathrm{mg} / \mathrm{kg}$ p.o.) while test groups received PE and HA extract (50, 100 and $200 \mathrm{mg} / \mathrm{kg}$ p.o.).

\section{Different treatments}

Three sets of test doses (50, 100 and $200 \mathrm{mg} / \mathrm{kg}$ of body weight) were prepared by suspending dried extracts in vehicle. Diazepam $2 \mathrm{mg} / \mathrm{kg}$ suspended in vehicle was used as a standard anxiolytic drug. Vehicle (1\% CMC) was used as control. The effects of the various treatments were estimated $45 \mathrm{~min}$ after the oral administration of vehicle/ standard drug/ test extracts. The entire tests were carried out between 8:00-14:00. In each experiment, apparatus was cleaned using 5\% ethanol before introducing the next animal to preclude the possible cueing effects of odours left by previous subjects.

\section{Animal Model for Anxiety \\ Elevated Plus Maze}

The plus maze apparatus consisting of two open arms $(16 \times 5 \mathrm{~cm})$ and two closed arms $(16 \times 5 \times 12 \mathrm{~cm}$ ) having an open roof with a plus maze elevated $(25 \mathrm{~cm})$ from the floor was used to observe anxiolytic behaviour of animals. The animals were fasted $18 \mathrm{~h}$ prior to experiment. The dose administration schedule was so adjusted that each mouse was having its turn on plus maze after 45 min of administration of dose. Each animal was placed in the centre of the elevated plus maze with its head facing the open arms.

During the $5 \mathrm{~min}$ experiment, behaviour of the mice was noted as a) preference of the animal for its first entry to open/closed arm b) number of entries into the open arm c) average time spent by the animal in open arm. The antianxiety activity was recorded as average time spent by the animals in the open arms of the EPM. During the entire experiment, each animal was allowed to socialize. Every precaution was taken to ensure that no external stimuli disturbed the animal. ${ }^{38}$

\section{Mirror chamber Test}

The mirror chamber consisted of wooden chamber $(40 \times 40 \times 30.5 \mathrm{~cm})$ having a mirror $(30 \times 30 \times 30 \mathrm{~cm})$ enclosed within it. Placement of the mirrored cube into the centre of the container forms a $5 \mathrm{~cm}$ corridor that completely surrounds the mirror chamber. The animals were placed individually into the chambers of the mirrors at a fixed corner.

During the 5 min experiment following parameters was noted a) latency to enter mirror chamber b) number of entries into the mirror chamber c) total time spent in the mirror chamber. ${ }^{38}$

\section{Hole-Board Test}

The hole board apparatus consisted of a wooden box $(40 \times 40 \times 25 \mathrm{~cm})$ with 16 holes (each of diameter $3 \mathrm{~cm}$ ) evenly distributed on the base of box. The apparatus was elevated to a height of $25 \mathrm{~cm}$. The number of head dips and the time of head dipping during a $5 \mathrm{~min}$ period were recorded..$^{39}$

\section{Statistical Analysis}

All the values were expressed as mean \pm SEM. Statistically significant difference between the groups were calculated by the application of one way analysis of variance (ANOVA) followed by Tukey's, post-hoc test. ${ }^{* * *} \mathrm{P}<0.001$ and ${ }^{* *} \mathrm{P}<0.01$ were considered statistically significant.

\section{RESULTS}

Yield of extracts: The yield of petroleum ether extract was $1.5 \% \mathrm{w} / \mathrm{w}$ and hydroalcoholic extract was $2.5 \% \mathrm{w} / \mathrm{w}$ on dry weight basis.

Phytochemical Screening: The results of phytochemical screening of B. oleracea are shown in Table 1.

Physicochemical evaluation: The results of various pharmacognostic parameters assessed are shown in Table 2.

Elevated Plus maze model: Diazepam ( $2 \mathrm{mg} / \mathrm{kg}$ ) showed anxiolytic activity, by showing significant $\left({ }^{* *} \mathrm{P}<0.001\right)$ increase in average time spent and frequency in open arms. The groups of mice treated with HA $(200 \mathrm{mg} / \mathrm{kg})$ and HA $(100 \mathrm{mg} / \mathrm{kg})$ have shown anxiolytic activity, significant $\left({ }^{* *} \mathrm{P}<0.001,{ }^{* *} \mathrm{P}<0.01\right)$ in the open arms in comparison to control group as shown in Figure 1 and 2. 
Table 1: Phytochemical analysis of extracts of Brassica oleracea L.

\begin{tabular}{|c|c|c|}
\hline Tests & $\begin{array}{c}\text { Petroleum ether } \\
\text { extract }\end{array}$ & $\begin{array}{c}\text { Hydroalcoholic } \\
\text { extract }\end{array}$ \\
\hline \multicolumn{3}{|l|}{ 1. Alkaloids } \\
\hline (a) Mayer's Test & - & + \\
\hline (b) Wagner's Test & - & + \\
\hline (c) Hager's Test & - & + \\
\hline (d) Dragendroff Test & - & + \\
\hline \multicolumn{3}{|l|}{ 2. Carbohydrates } \\
\hline (a) Molisch's Test & - & + \\
\hline (b) Benedict's Test & - & + \\
\hline (c) Fehling's Test & - & + \\
\hline \multicolumn{3}{|l|}{ 3. Glycosides } \\
\hline \multicolumn{3}{|l|}{ (Anthraquinone glycosides) } \\
\hline (a) Borntrager's Test & - & - \\
\hline (b) Modified Borntrager's Test & - & - \\
\hline \multicolumn{3}{|l|}{ (Cardiac glycosides } \\
\hline (c) Killer Killiani's test & - & - \\
\hline (d) Legal's Test & - & - \\
\hline \multicolumn{3}{|l|}{ 4. Saponins } \\
\hline (a) Froth test & - & - \\
\hline \multicolumn{3}{|l|}{ 5. Phytosterols } \\
\hline (a) Salkowski’s Test & - & + \\
\hline (b) LibermannBurchard's test & - & + \\
\hline \multicolumn{3}{|l|}{ 6. Phenols } \\
\hline (a) Ferric Chloride Test & - & + \\
\hline \multicolumn{3}{|l|}{ 7. Tannins } \\
\hline (a) Gelatin Test & - & + \\
\hline \multicolumn{3}{|l|}{ 8. Flavonoids } \\
\hline (a) Alkaline Reagent Test & - & + \\
\hline (b) Lead acetate Test & - & + \\
\hline (c) Shinoda Test & - & + \\
\hline \multicolumn{3}{|l|}{ 9. Proteins and aminoacids } \\
\hline (a) Xanthoproteic Test & + & + \\
\hline (b) Ninhydrin Test & + & + \\
\hline \multicolumn{3}{|l|}{ 10. Diterpenes } \\
\hline (a) Copper acetate Test & + & + \\
\hline
\end{tabular}

\section{Table 2: Results of pharmacognostic parameters}

\begin{tabular}{lc}
\hline \multicolumn{1}{c}{ Pharmacognostic parameters } & Mean \pm SEM $(n=3)$ \\
\hline 1. Loss on Drying & $0.33 \pm 0.165 \% \mathrm{w} / \mathrm{w}$ \\
2. Ash value & \\
a) Total ash & $1.82 \pm 1.82 \% \mathrm{w} / \mathrm{w}$ \\
b) Acid insoluble ash & $0.146 \pm 0.122 \% \mathrm{w} / \mathrm{w}$ \\
c) Water soluble ash & $2.42 \pm 1.22 \% \mathrm{w} / \mathrm{w}$ \\
3. Extractive value & \\
a) Water soluble extract & $2.5 \pm 1.52 \% \mathrm{w} / \mathrm{w}$ \\
b) Alcohol soluble extract & $2.0 \pm 1.9 \% \mathrm{w} / \mathrm{w}$ \\
\hline
\end{tabular}

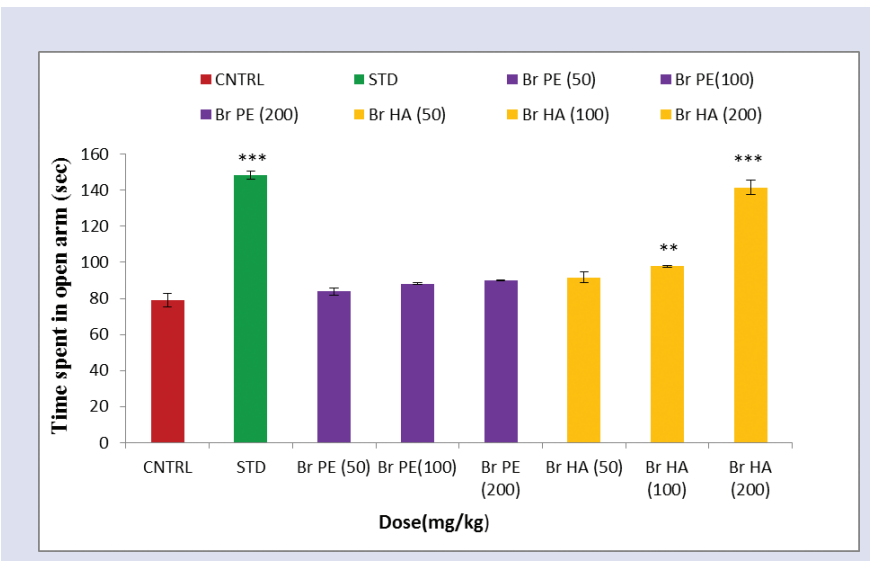

Figure 1: Effect of different extracts of Brassica oleracea on the time spent by mice in the open arms of the EPM CNTRL=control ( $2 \%$ CMC p.o.), STD=Diazepam ( $2 \mathrm{mg} / \mathrm{kg}$ p.o.), Br PE=petroleum ether extract (50, 100 and $200 \mathrm{mg} / \mathrm{kg}$ p.o.), Br HA=hydroalcoholic extract (50, 100 and $200 \mathrm{mg} / \mathrm{kg}$ p.o). Results are expressed as mean \pm SEM $(n=6) ;{ }^{* * *}$ $\mathrm{P}<0.001$ and ${ }^{* *} \mathrm{P}<0.01$ as compared to control.

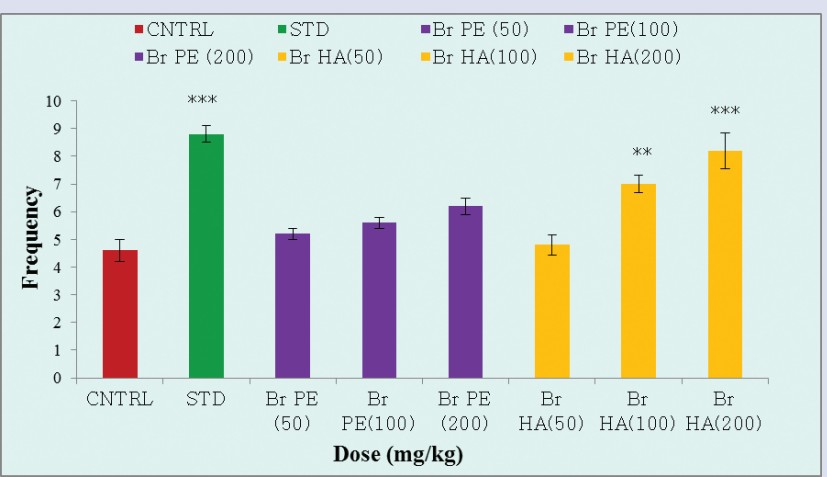

Figure 2: Effect of different extracts of Brassica oleracea on number of entries (frequency) by mice in the open arms of the EPM CNTRL=control ( $2 \%$ CMC p.o.), STD=Diazepam ( $2 \mathrm{mg} / \mathrm{kg}$ p.o.), $\mathrm{Br} \mathrm{PE}=$ petroleum ether extract $(50,100$ and $200 \mathrm{mg} / \mathrm{kg}$ p.o.), $\mathrm{Br}$ $\mathrm{HA}=$ hydroalcoholic extract (50, 100 and $200 \mathrm{mg} / \mathrm{kg}$ p.o). Results are expressed as mean \pm SEM $(n=6) ;{ }^{* * *} P<0.001$ and ${ }^{* *} P<0.01$ as compared to control.

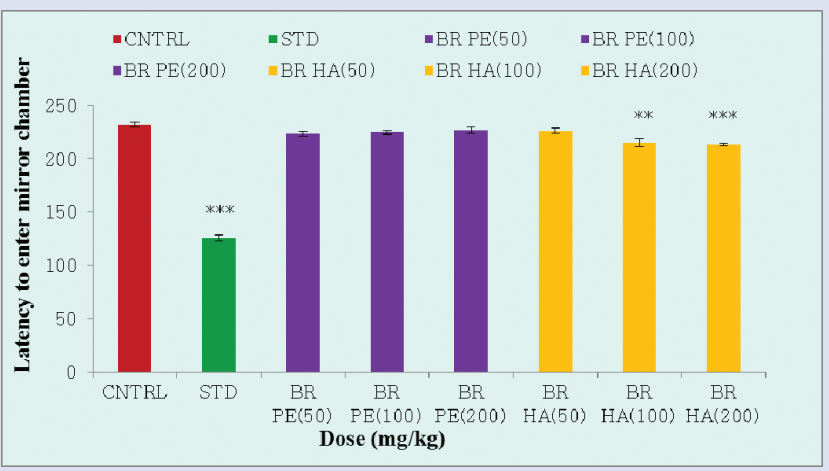

Figure 3: Effect of different extracts of Brassica oleracea on the latency to enter mirror chamber by mice in the mirror chamber test CNTRL=control (2\% CMC p.o.), STD=Diazepam ( $2 \mathrm{mg} / \mathrm{kg}$ p.o.), $\mathrm{Br}$ $\mathrm{PE}=$ petroleum ether extract (50, 100 and $200 \mathrm{mg} / \mathrm{kg}$ p.o.), BR $\mathrm{HA}=$ hydroalcoholic extract $(50,100$ and $200 \mathrm{mg} / \mathrm{kg} \mathrm{p.o)}$. Results are expressed as mean \pm SEM $(n=6) ;{ }^{* *} P<0.001$ and ${ }^{* *} P<0.01$ as compared to control. 


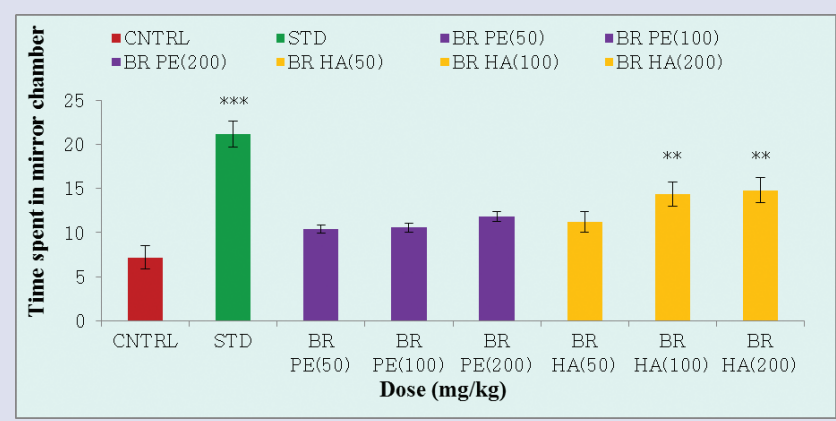

Figure 4: Effect of different extracts of Brassica oleracea on the time spent by mice in the mirror chamber in the mirror chamber test CNTRL=control ( $2 \%$ CMC p.o.), STD=Diazepam ( $2 \mathrm{mg} / \mathrm{kg}$ p.o.), Br $\mathrm{PE}=$ petroleum ether extract (50, 100 and $200 \mathrm{mg} / \mathrm{kg}$ p.o.), BR $\mathrm{HA}=$ hydroalcoholic extract (50, 100 and $200 \mathrm{mg} / \mathrm{kg} \mathrm{p.0).} \mathrm{Results} \mathrm{are}$ expressed as mean \pm SEM $(n=6)$; ${ }^{* *} P<0.001$ and ${ }^{* *} P<0.01$ as compared to control.

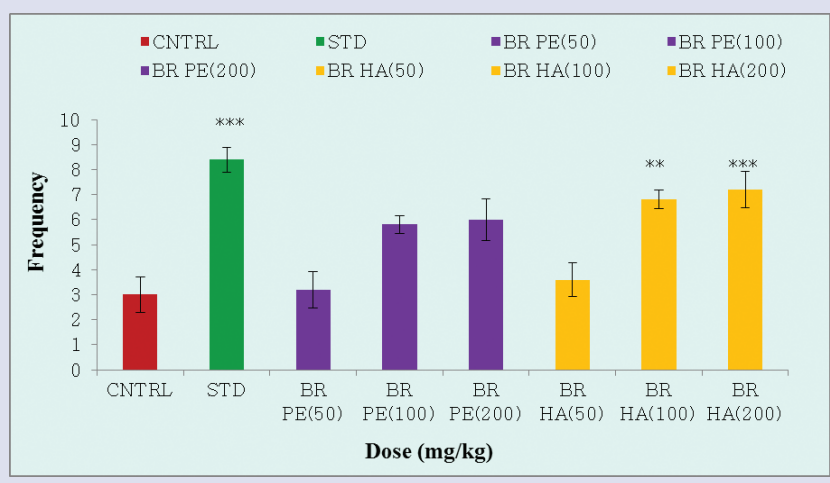

Figure 5: Effect of different extracts of Brassica oleracea on the number of entries (frequency) by mice in the mirror chamber in the mirror chamber test CNTRL=control ( $2 \%$ CMC p.o.), STD=Diazepam ( $2 \mathrm{mg} / \mathrm{kg}$ p.o.), $\mathrm{Br} \mathrm{PE}=$ petroleum ether extract (50, 100 and $200 \mathrm{mg} / \mathrm{kg}$ p.o.), BR $\mathrm{HA}=$ hydroalcoholic extract $(50,100$ and $200 \mathrm{mg} / \mathrm{kg} \mathrm{p.o)}$. Results are expressed as mean \pm SEM $(n=6) ;{ }^{* * *} P<0.001$ and ${ }^{* *} P<0.01$ as compared to control.

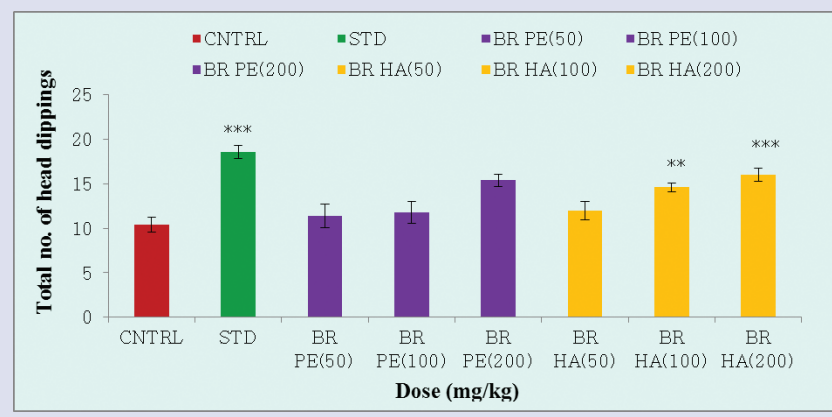

Figure 6: Effect of different extracts of Brassica oleracea on the number of head dippings by mice in the the hole board test CNTRL=control ( $2 \%$ CMC p.o.), STD=Diazepam ( $2 \mathrm{mg} / \mathrm{kg}$ p.o.), Br PE=petroleum ether extract (50, 100 and $200 \mathrm{mg} / \mathrm{kg}$ p.o.), BR HA=hydroalcoholic extract (50, 100 and $200 \mathrm{mg} / \mathrm{kg}$ p.o). Results are expressed as mean \pm SEM $(n=6) ;{ }^{* *} P<0.001$ and ${ }^{* *} P<0.01$ as compared to control.
Mirror chamber Test: The groups of mice treated with HA $(200 \mathrm{mg} / \mathrm{kg})$ and HA $(100 \mathrm{mg} / \mathrm{kg})$ have shown decrease in latency, increase in time spent and frequency in the mirror chamber significant ${ }^{* * *} \mathrm{P}<0.001$, $\left.{ }^{* *} \mathrm{P}<0.01\right)$ in comparison to control as shown in Figure 3, 4 and 5.

Hole board Test: With the dose of $50 \mathrm{mg} / \mathrm{kg}$, HA extract of broccoli, there was no significant increase in number of head dips as compared to control. HA extract at 200 and $100 \mathrm{mg} / \mathrm{kg}$ increased the number of head dips significantly ${ }^{* * *} \mathrm{P}<0.001,{ }^{* *} \mathrm{P}<0.01$ ). The standard group showed significant increase in number of head dips $\left({ }^{* * *} \mathrm{P}<0.001\right)$ as shown in 6.

\section{DISCUSSION}

The brain is highly vulnerable to oxidative stress. Oxidative stress can alter neurotransmission, neuronal function and overall brain activity. Oxidative stress has been implicated in neurodegenerative diseases and neuropsychiatric diseases including stress and anxiety. ${ }^{6}$ Antioxidant therapy has been reported to have a protective effect in anxiety disorders. Polyphenols, flavonoids, specific foods and diets rich in antioxidants have been shown to improve antioxidant status and have anxiolytic effects. ${ }^{7,9}$ Plant extracts, which contain phenolic constituents mainly flavonoids, have shown beneficial effects on mental health. Extracts of plants like Pulsatilla nigricans ${ }^{40}$ Tephrosia purpuria ${ }^{41}$ Coriandrum sativum ${ }^{42}$ Gastrodia elata, ${ }^{43}$ Citrus paradisi ${ }^{44}$ contain flavonoids and possess antianxiety activity. Flavonoids have been reported to possess antianxiety potential. ${ }^{12}$ Flavonoids and Diazepam are structurally similar. ${ }^{45-12}$ Searching for safer BDZ-receptor (BDZ-R) ligands has demonstrated the existence of a new family of ligands which have a flavonoid structure. Brassica oleracea contains large amounts of polyphenols specially flavonoids. ${ }^{46}$ Thus, for the present investigation, Broccoli (Brassica oleracea) that contains phenolic compounds and has marked antioxidant activity has been selected and evaluated for its anxiolytic potential. Thus, the antianxiety effect of $B$. oleracea extracts was evaluated on experimental animals using various models. Various physicochemical parameters of the plant were also evaluated which have not been determined so far.

The Elevated Plus Maze is considered to be a valid animal model of anxiety because it uses natural stimulus that is the fear of a new, brightly light open space and the fear of balancing on a relatively narrow raised platform. ${ }^{47}$ Moreover, it is known that anxiolytic agents increase the frequency of entries and the time spent in open arms of the Elevated Plus Maze. ${ }^{48}$ In the present study, HA extract markedly increased the frequency of entries and the time spent by the animals in the open arms. The Hole-Board test provides a simple method for measuring the response of an animal to an unfamiliar environment. It has been showed that head-dipping behaviour was sensitive to changes in the emotional state of the animal, and suggested that the expression of an anxiolytic state in animals may be reflected by an increase in head-dipping behaviour. In the present study, HA extract at 200 and $100 \mathrm{mg} / \mathrm{kg}$ increased the number of head dips significantly.

Animal species exhibit approach avoidance conflict upon placement of a mirror. The extended latency to enter mirror chamber is a parameter of anxiety analogy. In the present study, HA extract has shown decrease in latency, increase in time spent and frequency of entries in the mirror chamber.

The results of the behavioural tests clearly demonstrate that the HA extract shows distinct potential for being developed as an anti-anxiety drug. The phytochemical study showed the presence of phenols and flavonoids in the bioactive extract.

\section{CONCLUSION}

From our research study, it is concluded that hydroalcoholic extract of Brassica oleracea after acute dosing possess significant anxiolytic activity 
at dose of $200 \mathrm{mg} / \mathrm{kg}$. The petroleum ether extract was devoid of antianxiety effect. Further studies are being conducted to ascertain the bioactive constituent responsible for the activity.

\section{ACKNOWLEGMENT}

Authors are thankful to I.K. Gujral Punjab Technical University and Chandigarh College of Pharmacy for the help and facilities provided to conduct this study.

\section{CONFLICT OF INTEREST}

Authors have no conflict of interest.

\section{ABBREVIATION USED}

EPM: Elevated Plus Maze; PE: Petroleum ether; HA: Hydroalcoholic.

\section{REFERENCES}

1. Kulkarni SK, Reddy DS. Animal behavioural models for testing antianxiety agents. Methods and Findings in Experimental and Clinical Pharmacology. 1996;18(3):219-30. PMid:8738074

2. Yadav AV, Kawale LA, Nade VS. Effect of Morus alba L.(mulberry) leaves on anxiety in mice. Indian Journal of Pharmacology. 2008;40(1):32. https://doi. org/10.4103/0253-7613.40487; PMid:21264159 PMCid:PMC3023120

3. Rauniar GP, Deo S, Bhattacharya SK. Evaluation of anxiolytic activity of tensarin in mice. Kathmandu Univ Med. J 2007;18:188-94.

4. Lader M, Morton S. Benzodiazepine problems. British J Addict. 1991;86:823-28. https://doi.org/10.1111/j.1360-0443.1991.tb01831.x.

5. Griffiths RR, Ator NA, Roache JD, Lamb RJ. Abuse liability of triazolam: experimental measurements in animals and humans. Psychopharmacol Research. 1987;3:83-7. https://doi.org/10.1007/978-3-642-71288-3_10.

6. Bouayed J, Rammal H, Soulimani R. Oxidative stress and anxiety. Oxid Med Cell Longev. 2009;2:63-7. https://doi.org/10.4161/oxim.2.2.7944; PMid:20357926 PMCid:PMC2763246.

7. Gautam M, Agrawal M, Gautam M, Sharma P, Gautam AS, et al. Role of antioxidants in generalised anxiety disorder and depression. Indian Journal of Psychiatry. 2012;54(3):244. https://doi.org/10.4103/0019-5545.102424; PMid:23226848 PMCid:PMC3512361.

8. Agati G, Azzarello E, Pollastri S, Tattini M. Flavonoids as antioxidants in plants: location and functional significance. Plant Science. 2012;196:67-76. https://doi. org/10.1016/j.plantsci.2012.07.014; PMid:23017900.

9. Pietta PG. Flavonoids as antioxidants. J Nat Prod. 2000;63:1035-42. https://doi. org/10.1021/np9904509; PMid:10924197.

10. Salah N, Miller NJ, Paganga G, Tijburg L, Bolwell GP, et al. Polyphenolic flavanols as scavengers of aqueous phase radicals and as chain-breaking antioxidants. Archives of Biochemistry and Biophysics. 1995;322(2):339-46. https://doi. org/10.1006/abbi.1995.1473; PMid:7574706.

11. Medina JH, Viola $\mathrm{H}$, Wolfman $\mathrm{C}$, Marder M, Wasowski $\mathrm{C}$, et al. Neuroactive flavonoids: new ligands for the benzodiazepine receptors. Phytomedicine. 1998;5(3):235-43. https://doi.org/10.1016/S0944-7113(98)80034-2.

12. Paladini AC, Marder M, Viola H, Wolfman C, Wasowski $C$, et al. Flavonoids and the central nervous system: from forgotten factors to potent anxiolytic compounds. Journal of Pharmacy and Pharmacology. 1999;51(5):519-26. https://doi. org/10.1211/0022357991772790; PMid:10411210.

13. Kumar D, Kumar S. Screening of antianxiety activity of Abies pindrow Royle aerial parts. Indian Journal of Pharmaceutical Education and Research. 2015;49(1):66-70. https://doi.org/10.5530/ijper.49.1.9.

14. Kumar D, Kumar S. Evaluation of antianxiety activity of Calotropis gigantea L. roots. J Fundam Pharm Res. 2014;2:30-7.

15. Viola H, Wasowski C, De Stein ML, Wolfman C, Silveira R, et al. Apigenin, a component of Matricaria recutita flowers, is a central benzodiazepine receptors-ligand with anxiolytic effects. Planta Medica. 1995;61(03):213-6. https:// doi.org/10.1055/s-2006-958058; PMid:7617761.

16. Dutt V, Dhar VJ, Sharma A. Antianxiety activity of Gelsemium sempervirens. Pharmaceutical Biology. 2010;48(10):1091-6. https://doi.org/10.3109/ 13880200903490521 ; PMid:20860436.

17. Singh Bora K, Sharma A. Evaluation of anxiolytic effect of Medicago sativa in mice. Pharmaceutical Biology. 2012;50(7):878-82. https://doi.org/10.3109/13880 209.2011.641227; PMid:22489538

18. Wolfman C, Viola H, Paladini A, Dajas F, Medina JH. Possible anxiolytic effects of chrysin, a central benzodiazepine receptor ligand isolated from Passiflora coerulea. Pharmacology Biochemistry and Behavior. 1994;47(1):1-4. https://doi. org/10.1016/0091-3057(94)90103-1.

19. Soulimani R, Younos C, Jarmouni S, Bousta D, Misslin R, et al. Behavioura effects of Passiflora incarnata L. and its indole alkaloid and flavonoid derivatives and maltol in the mouse. Journal of Ethno Pharmacology. 1997;57(1):11-20. https://doi.org/10.1016/S0378-8741(97)00042-1.

20. Herrera-Ruiz M, Román-Ramos R, Zamilpa A, Tortoriello J, Jiménez-Ferrer JE. Flavonoids from Tilia americana with anxiolytic activity in plus-maze test. Journal of Ethnopharmacology. 2008;118(2):312-7. https://doi.org/10.1016/j. jep.2008.04.019; PMid:18539420.

21. Kumar S, Sharma A. Apigenin: The Anxiolytic Constituent of Turnera aphrodisiaca. Pharmaceutical Biology. 2006;44(2):84-90. https://doi.org/10.1080/ 13880200600591758.

22. Kumar S, Madaan R, Sharma A. Pharmacological evaluation of bioactive principle of Turnera aphrodisiaca. Indian Journal of Pharmaceutical Sciences. 2008;70(6):740. https://doi.org/10.4103/0250-474X.49095; PMid:21369434 PMCid:PMC3040867.

23. Zanoli P, Avallone R, Baraldi M. Behavioral characterisation of the flavonoids apigenin and chrysin. Fitoterapia. 2000;71:S117-23. https://doi.org/10.1016/ S0367-326X(00)00186-6.

24. Grundmann O, Nakajima JI, Kamata K, Seo S, Butterweck V. Kaempferol from the leaves of Apocynum venetum possesses anxiolytic activities in the elevated plus maze test in mice. Phytomedicine. 2009;16(4):295-302. https:// doi.org/10.1016/j.phymed.2008.12.020; PMid:19303276.

25. Singh B, Sharma V, Pal Singh Ishar M, Sharma A. Bioactivity Guided Isolation of Quercetin as Anxiolytic Compound from Elaeocarpus ganitrus Beads. The Natural Products Journal. 2013;3(3):224-9. https://doi.org/10.2174/22103155113 039990010 .

26. Chun OK, Kim DO, Smith N, Schroeder D, Han JT, et al. Daily consumption of phenolics and total antioxidant capacity from fruit and vegetables in the American diet. Journal of the Science of Food and Agriculture. 2005:85(10):1715-24. https://doi.org/10.1002/jsfa.2176.

27. Bahorun $T$, Luximon-Ramma A, Crozier A, Aruoma Ol. Total phenol, flavonoid, proanthocyanidin and vitamin $\mathrm{C}$ levels and antioxidant activities of Mauritian vegetables. Journal of the Science of Food and Agriculture. 2004;84(12):1553-61. https://doi.org/10.1002/jsfa.1820.

28. Leja M, Mareczek A, Starzynska A, Rozek S. Antioxidant ability of broccoli flower buds during short-term storage. Food Chemistry. 2001;72(2):219-22. https://doi. org/10.1016/S0308-8146(00)00224-7.

29. Owis Al. Broccoli; The Green Beauty: A Review. J Pharm Sci and Res. 2015;7:696-703

30. Plumb GW, Price KR, Modes MJ, Williamson G. Antioxidant properties of the major polyphenolic compounds in broccoli. Free Radical Research. 1997:27(4):42935. https://doi.org/10.3109/10715769709065782; PMid:9416471.

31. Sibi G, Shukla A, Dhananjaya K, Ravikumar KR, Mallesha H. In vitro antibacterial activities of Broccoli (Brassica oleracea L. var italica) against food borne bacteria.

32. Lemos M, Santin JR, Júnior LC, Niero R, de Andrade SF. Gastroprotective activity of hydroalcoholic extract obtained from the leaves of Brassica oleracea var. acephala DC in different animal models. Journal of Ethnopharmacology. 2011;138(2):503-7. https://doi.org/10.1016/j.jep.2011.09.046; PMid:21986229.

33. Matusheski NV, Swarup R, Juvik JA, Mithen R, Bennett M, et al. Epithiospecifier protein from broccoli (Brassica oleracea L. ssp. italica) inhibits formation of the anticancer agent sulforaphane. Journal of Agricultural and Food Chemistry. 2006;54(6):2069-76. https://doi.org/10.1021/jf0525277; PMid:16536577.

34. Haque S, NaznineT, Ali M, AzadTT, MorshedT, Afsana NA, Ahmed I, Rahmatullah M. Antihyperglycemic activities of leaves of Brassica oleracea, Centella asiatica and Zizyphus mauritiana: Evaluation through oral glucose tolerance tests. Advances in Natural and Applied Sciences. 2013;7(5):519-26.

35. Sankhari JM, Thounaojam MC, Jadeja RN, Devkar RV, Ramachandran AV. Anthocyanin-rich red cabbage (Brassica oleracea L.) extract attenuates cardiac and hepatic oxidative stress in rats fed an atherogenic diet. Journal of the Science of Food and Agriculture. 2012;92(8):1688-93. https://doi.org/10.1002/ jsfa.5532; PMid:22228433.

36. World Health Organisation (WHO): Monographs for Selected Medicinal Plants. WHO, Geneva, Vol. II, 2002

37. Farnsworth NR. Biological and phytochemical screening of plants. Journal of Pharmaceutical Sciences. 1966;55(3):225-76. https://doi.org/10.1002/ jps.2600550302; PMid:5335471.

38. Kulkarni SK. Practical Pharmacology and Clinical Pharmacy. $1^{\text {st }}$ ed. Delhi: Vallabh Prakasan;2009.

39. Brown GR, Nemes C. The exploratory behaviour of rats in the hole-board apparatus: Is head-dipping a valid measure of neophilia?. Behavioural Processes. 2008;78(3):442-8. https://doi.org/10.1016/j.beproc.2008.02.019; PMid:18406075 PMCid:PMC2396234.

40. Goyal S, Kumar S. Anti-anxiety activity studies of various extracts of Pulsatilla nigricans Stoerck. Int J Pharm Sci Drug Res. 2010;2(4):291-3.

41. Kumar AS, Amudha P, Kannan CS. Evaluation of anxiolytic activity of hydroalcoholic activity of Tephrosia purpuria (I) pers on swiss albino mice. International Journal of Pharmaceutical Sciences and Research. 2011;2(5):1262.

42. Mahendra $P$, Bisht S. Anti-anxiety activity of Coriandrum sativum assessed using different experimental anxiety models. Indian journal of pharmacology. 
2011;43(5):574. https://doi.org/10.4103/0253-7613.84975; PMid:22022003 PMCid:PMC3195130.

43. Jung JW, Yoon BH, Oh HR, Ahn JH, Kim SY, et al. Anxiolytic-like effects of Gastrodia elata and its phenolic constituents in mice. Biological and Pharmaceutical Bulletin. 2006;29(2):261-5. https://doi.org/10.1248/bpb.29.261; PMid:16462028.

44. Gupta V, Bansal P, Niazi J, Kaur G. Anti-anxiety Activity of Citrus paradisi var. star ruby Extracts. International Journal of PharmTech Research. 2010;2(3):1655-7.

45. Griebel G, Perrault G, Tan S, Schoemaker H, Sanger DJ. Pharmacological studies on synthetic flavonoids: comparison with diazepam. Neuropharmacology.
1999;38(7):965-77. https://doi.org/10.1016/S0028-3908(99)00026-X

46. Cartea ME, Francisco M, Soengas P, Velasco P. Phenolic compounds in Brassica vegetables. Molecules. 2010;16(1):251-80. https://doi.org/10.3390/molecules 16010251; PMid:21193847.

47. Dawson GR, Tricklebank MD. Use of the elevated plus maze in the search for novel anxiolytic agents. Trends in Pharmacological Sciences. 1995 Feb 28;16(2):33-6. https://doi.org/10.1016/S0165-6147(00)88973-7.

48. Pellow S, Chopin P, File SE, Briley M. Validation of open: closed arm entries in an elevated plus-maze as a measure of anxiety in the rat. Journal of Neuroscience Methods. 1985;14(3):149-67. https://doi.org/10.1016/0165-0270(85)90031-7.

\section{GRAPHICAL ABSTRACT}

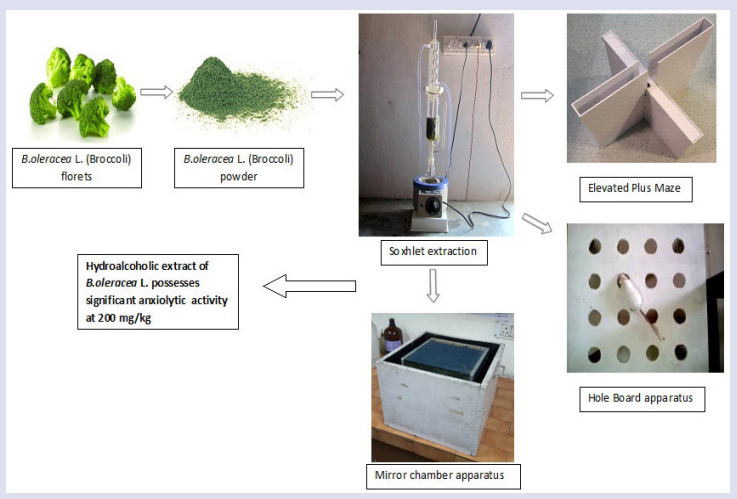

\section{HIGHLIGHTS OF PAPER}

- Various pharmacognostic parameters of the plant material were studied following standard procedures.

- Powdered drug was subjected to successive exhaustive extraction with petroleum ether and methanol:water (70:30) in the soxhlet apparatus and PE and HA extracts were prepared.

- The anxiolytic effects were evaluated by Elevated Plus Maze (EPM), hole board and mirror chamber tests and stastical analysis was done by using one way analysis of variance (ANOVA) followed by Tukey's, post-hoc test.

- Results showed that hydroalcoholic extract of Brassica oleracea after possess significant anxiolytic activity at dose of $200 \mathrm{mg} / \mathrm{kg}$. The petroleum ether extract was devoid of anti-anxiety effect.

- The phytochemical study showed the presence of phenols and flavonoids in the bioactive extract.

\section{AUTHOR PROFILE}

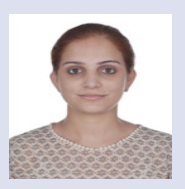

Divneet Kaur: Is Reseach Scholar at I.K.G.PTU., Jalandhar. She is currently working as an Assistant Prof. at G.H.G. Khalsa College of Pharmacy, Gurusar Sadhar, Ludhiana. Her area of research includes research on CNS activities of medicinal plants.

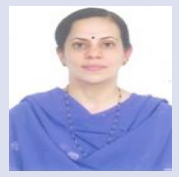

Dr. Richa Shri: Is Professor at Dept. of Pharmaceutical Sciences and Drug Research, Punjabi University, Patiala. Her areas of research interest include evaluation of plants and mushrooms with neuroprotective effect, CNS activities, antidiabetic effect. She has more than 42 research and review article of international repute to her credit.

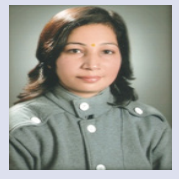

Dr. Anjoo Kamboj: Is presently working as Professor in Chandigarh College of Pharmacy, Landran, Mohali, Punjab, India. She has contributed more than 40 research and review article of international repute. Her areas of interest are phytoconstituents isolation, identification, characterization and its quantitative and pharmacological evaluation.

Cite this article : Kaur D, Shri R, Kamboj A. Evaluation of Anti-Anxiety Effect of Brassica oleracea L. Extracts in Experimental Animals. Pharmacogn J. 2017;9(5):638-43. 